\title{
A reforma do Estado nos anos 90 e suas implicações para as políticas públicas educacionais na região amazônica
}

\author{
Paulo Sérgio de Almeida Corrêa \\ Professor do Centro de Educação da Universidade Federal do Pará
}

\section{Resumo}

O artigo discute como está sendo desencadeado o processo de reforma do Estado no Brasil, detendo-se nas implicações que esse reordenamento tem trazido para as políticas públicas educacionais que começaram a ser implementadas na região amazônica pelo gestor público paraense a partir dos anos 90. Orientado pela hipótese de que as políticas educacionais colocadas em prática na região amazônica pelo governo do Estado do Pará

fundamentam-se nos princípios da administração pública gerencial, o estudo considera a relação dessa escolha com o processo mais amplo das mudanças ocorridas no modelo produtivo capitalista na atualidade.

\section{Abstract}

The article discusses how the State reform process has been developed in Brazil, focusing particularly the implications that this reordering has been bringing for the educational public politics, which began to be implemented in the amazon area by the government of the State of Pará since the second half of the nineties. Guided by the hypothesis that the educational politics practiced in the amazon area by the Para's Government are based on the guide lines of the managerial public administration, the study considers the relationship of that choice with the widest process of those changes happened at the present time on the world wide capitalism.

\section{Palavras-Chave}

Amazônia - Educação - Reforma do Estado - Pará

\section{Keywords}

Amazonian - Education - State reform Pará 


\section{Introdução}

No presente artigo tenho por objetivo discutir como está sendo desencadeado o processo de reforma do Estado no Brasil, detendo-me especificamente nas implicações que esse reordenamento tem trazido para as políticas públicas educacionais que começaram a ser implementadas na região amazônica pelo gestor público paraense a partir dos anos 90 .

Para efeito deste estudo, tomarei como objeto de análise as ações executadas no decorrer das duas gestões administrativas de Almir Gabriel, que se encontra à frente do poder no Estado do Pará desde 1995. Assim, o foco será posto nas medidas concernentes às políticas educacionais acionadas nesse período em nível local, a fim de perceber as suas confluências em relação ao conjunto de metas fixadas pelo governo federal para o setor educacional.

Nesta pesquisa adoto como hipótese de trabalho o argumento segundo o qual as políticas educacionais colocadas em prática na região amazônica pelo governo do Estado do Pará fundamentam-se nos princípios da administração pública gerencial, sendo esta última assumida pela atual gestão governamental enquanto estratégia capaz de viabilizar a organização eficiente do sistema escolar, tendo em vista a oferta de uma educação de qualidade a todos os cidadãos que dela necessitem.

O estudo acerca das políticas educacionais no Brasil não deve ser realizado sem se considerar a sua relação com o processo mais amplo das mudanças ocorridas no modelo produtivo capitalista na atualidade. Para viabilizar as metas estabelecidas pelo sistema capitalista, a reforma dos Estados Nacionais torna-se um instrumento operacional de primeira ordem. Partindo desses pressupostos, formulo as seguintes indagações iniciais: De que maneira vem sendo conduzido o processo de reforma do Estado no Brasil dos anos noventa? Como as mudanças na função do Estado estão afetando as políticas educacionais constituídas no âmbito das unidades federadas?

O presente texto estrutura-se em três momentos centrais: 1) a discussão teórica acerca dos princípios norteadores da reforma do Estado brasileiro nos anos 90; 2) as repercussões e os efeitos do modelo da administração pública gerencial na unidade federada do Pará; 3) as implicações da implementação da administração pública gerencial para o campo educacional.

\section{Alguns princípios basilares da reforma do Estado brasileiro nos anos 90}

O processo de globalização econômica associado ao uso das novas tecnologias no setor produtivo está a exigir modificações nas relações 
de trabalho bem como nas leis trabalhistas que as regem. Com isso, advoga-se a necessidade de um novo papel a ser assumido pelo Estado em relação às políticas públicas e de emprego em nível mundial.

Ao estudar a problemática da reforma do Estado e as relações desta com as políticas públicas no Brasil, Dain e Soares (1998, p. 31-72) localizam nos anos 80 o início desse processo reformista. As autoras mostram que, embora a Constituição de 88 tenha se preocupado em "universalizar a proteção social e ao mesmo tempo promover a descentralização das políticas públicas", tais metas pouco se efetivaram na prática, pois a partir dos anos 90 começaram a ser executadas ações por parte do governo federal, no intuito de "desmontar" o modelo de Estado preconizado naquele texto constitucional.

De acordo com as análises das referidas pesquisadoras, a reforma do Estado brasileiro que está atualmente em curso revela-se profundamente descompromissada e omissa no que concerne à política pública de proteção social, assim como à questão da cidadania, uma vez que os seus fundamentos assentam-se numa "conotação meramente 'administrativa', não se constituindo em uma verdadeira Reforma do Estado" (Dain e Soares, 1998, p. 66).

Segundo as autoras, "a estratégia central da reforma em questão resume-se à substituição da 'administração burocrática' pela 'administração gerencial'". Partindo dessa premissa, elas enfatizam que "a reforma do Estado passa a ser apenas um instrumento para 'consolidar a estabilização e assegurar o crescimento sustentado da economia'" (Dain e Soares, 1998, p. 66). Assim, a solução mágica encontrada pelo Ministério de Administração e Reforma do Estado (MARE), ligado ao governo federal, baseia-se no seguinte princípio:

"O movimento básico para corrigir as 'distorções' ou os 'desvios' do Estado é a transferência para o setor privado daquelas atividades que podem ser 'controladas pelo mercado. Isto é feito através da privatização de todas as estatais... e da descentralização da execução de serviços (sociais) de educação, saúde, cultura e pesquisa a um setor público não-estatal" (Dain e Soares, 1998, p. 67-68).

Luiz Carlos Bresser Pereira desfruta na atualidade uma destacada posição como eminente ideólogo da reforma do Estado. Partindo das suas formulações teóricas, é possível apreender alguns dos princípios que estão norteando as mudanças desejadas para o Estado brasileiro nos anos 90 . 
Em um de seus escritos mais recentes, Bresser Pereira (1998) discute a problemática relativa à reforma do Estado, apontando caminhos que visam repensar a sua lógica de funcionamento e indicando os mecanismos de controle que podem torná-lo gerencialmente eficiente.

De acordo com a concepção de Bresser Pereira, são quatro os "problemas" que envolvem a reforma do Estado:

"a delimitação do tamanho do Estado; a redefinição do papel regulador do Estado; a recuperação da governança ou capacidade financeira e administrativa de implementar as decisões políticas tomadas pelo governo; o aumento da governabilidade ou capacidade política do governo de intermediar interesses, garantir legitimidade, e governar" (Bresser Pereira, 1998, p. 49-50).

A superação desses obstáculos depende do cumprimento das recomendações apresentadas como requisitos fundamentais para se atingir maior eficiência e eficácia na intervenção estatal, a fim de fortalecer o seu poder gerenciador.

Reconstruir o Estado, segundo esse autor (p. 58), significa dotá-lo de maior poder de modo que seja possível alcançar os seguintes resultados:

"recuperação da poupança pública e superação da crise fiscal; redefinição das formas de intervenção no econômico e no social através da contratação de organizações públicas não-estatais para executar os serviços de educação, saúde, e cultura; e reforma da administração pública com a implantação de uma administração pública gerencial. Reforma que significa transitar de um Estado que promove diretamente o desenvolvimento econômico e social para um Estado que atue como regulador e facilitador ou financiador a fundo perdido desse desenvolvimento"(Bresser Pereira, 1998, p. 58)1.

De acordo com a perspectiva defendida por Bresser Pereira ( $p$. 59-60), no século XXI, o Estado será configurado com base no seguinte arranjo institucional:

\footnotetext{
No artigo intitulado "Em busca de um novo paradigma: a reforma do Estado no Brasil dos anos 90", Eli Diniz defende o argumento de que é necessário "pensar a reforma do Estado em estreita conexão com o tema da consolidação democrática", pois, na sua concepção, "tratada de maneira isolada, como ocorre com freqüência, ou exclusivamente em função de seus aspectos administrativos, a reforma do Estado tende a ser conduzida de forma a acentuar as tensões com os requisitos da institucionalização da democracia". Para a referida autora, o processo de reforma do Estado não deve deter-se tão-somente na questão da governança e da governabilidade para dar-lhe maior eficácia e eficiência gerencial, pois "a crise do poder público não pode ser explicada sem que sejam levadas em consideração as especificidades do processo de constituição do Estado brasileiro e as tensões internas do modelo historicamente consolidado que, no decorrer do tempo, provocariam sua erosão" (Diniz, 1996, p. ).
} 
"Nossa previsão é a de que o Estado do século vinte-e-um será um Estado Social-Liberal: social porque continuará a proteger os direitos sociais e promover o desenvolvimento econômico; liberal, porque o fará usando os controles de mercado e menos os controles administrativos, porque realizará seus serviços sociais e científicos principalmente através de organizações públicas não-estatais competitivas, porque tornará os mercados de trabalhos mais flexíveis, porque promoverá a capacitação dos seus recursos humanos e de suas empresas para a inovação e a competição internacional" (Bresser Pereira, 1998, p. 59-60).

O receituário apresentado por Bresser Pereira (1998, p. 60) para orientar a reforma do Estado valoriza quatro "componentes ou processos básicos" indispensáveis à execução dessa proposta: a) a delimitação das funções do Estado, reduzindo o seu tamanho em termos principalmente de pessoal por meio de programas de privatização, terceirização e "publicização"; b) a redução do grau de interferência do Estado ao efetivamente necessário por meio de programas de desregulação que aumentem o recurso aos mecanismos de controle via mercado; c) o aumento da governança do Estado, ou seja, da sua capacidade de tornar efetivas as decisões do governo, por meio do ajuste fiscal; d) o aumento da governabilidade, ou seja, do poder do governo.

De acordo com a lógica gerencial atribuída por Bresser Pereira (1998, p. 66) ao Estado, as atividades da área social e científica deixariam de ser uma competência exclusiva do Estado, pois as escolas, as universidades, os centros de pesquisa científica e tecnológica, as creches, os ambulatórios, os hospitais, as entidades de assistência aos carentes "são atividades competitivas, que podem ser controladas não apenas através da administração pública gerencial, mas também e principalmente através do controle social e da constituição de quase-mercados". Segundo esse entendimento, "não há razão para que estas atividades permaneçam dentro do Estado, sejam monopólio estatal", pois a realização desses serviços passa a ser também concedida ao "setor público não-estatal", mediante um processo de publicização, privatização e terceirização.

Para Bresser Pereira, o funcionamento dessas instituições submeter-se-á a um triplo mecanismo de controle representado pelo Estado (entendido como sistema legal ou jurídico), pelo mercado (sistema econômico em que o controle se realiza por meio da competição) e pela sociedade civil (envolve os diversos grupos sociais). Contudo, nem o Estado, nem a sociedade civil são encarados como mecanismos de controle preferenciais, uma vez que no seu modo de ver 
"o mercado é o melhor mecanismo de controle, já que através da concorrência obtêm-se, em princípio, os melhores resultados com os menores custos e sem a necessidade do uso do poder, seja ele exercido democrática ou hierarquicamente. Por isso a regra geral é a de que, sempre que for possível, o mercado seja escolhido como mecanismo de controle" (Bresser Pereira, 1998, p. 75-76).

A questão da governança constitui um outro ponto de grande destaque na reforma do Estado nos anos 90. Ela está relacionada às condições financeiras e administrativas, sem as quais o governo não poderá concretizar as decisões e metas propostas em seu plano governamental.

Na concepção de Bresser Pereira, a governança tem como pressuposto básico a implementação de um modelo estabelecido a partir da "administração pública gerencial", cujas características principais são:

"orientação da ação do Estado para o cidadão-usuário ou cidadãocliente; ênfase no controle dos resultados através dos contratos de gestão; fortalecimento e aumento da autonomia da burocracia estatal; separação entre as secretarias formuladoras de políticas públicas, de caráter centralizado, e as unidades descentralizadas, executoras; distinção de dois tipos de unidades descentralizadas: as agências executivas e as organizações sociais; transferência para o setor público não-estatal dos serviços sociais e científicos competitivos; adoção cumulativa dos mecanismos de controle social direto, dos contratos de gestão e da formação de quase-mercados; terceirização das atividades auxiliares ou de apoio, que passam a ser licitadas competitivamente no mercado" (Bresser Pereira, 1998, p. 80-81).

Já a governabilidade representa um outro elemento central na composição da nova administração pública delineada por Bresser Pereira. Caracteriza-se pela capacidade política para governar e deriva da "relação de legitimidade do Estado e do seu governo com a sociedade" (Bresser Pereira, 1998, p. 88). Dentro dessa temática, o autor entende que

"reformar o Estado para lhe dar maior governabilidade é torná-lo mais democrático, é dotá-lo de instituições políticas que permitam uma melhor intermediação dos interesses sempre conflitantes dos diversos grupos sociais, das diversas etnias quando não nações, das diversas regiões do país" (Bresser Pereira, 1998, p. 88). 
A realização dessas medidas em conjunto trará um novo perfil para o Estado em sua articulação com o mercado e com a sociedade civil. No dizer de Bresser Pereira, as reformas estatais produzirão como resultado

"um Estado mais eficiente, que responda a quem de fato deve responder: o cidadão. Logo, será um Estado que estará agindo em parceria com a sociedade e de acordo com os seus anseios. Será um Estado menos voltado para a proteção e mais para a promoção da capacidade de competição. Será um Estado que não utilizará burocratas estatais para executar os serviços sociais e científicos, mas contratará competitivamente organizações públicas não-estatais" (Bresser Pereira, 1998, p. 89).

O modelo de Estado arquitetado por Bresser Pereira opera uma brutal destruição da noção de Estado enquanto síntese de múltiplas relações sociais, como o concebera Antônio Gramsci, para submetê-lo a uma função exclusivamente gerencial, burocrática e destinada a formular políticas adaptadas às demandas do mercado. Por outro lado, a sociedade civil perde seu poder contestador, transformando-se em espaço cuja prioridade reside em fiscalizar, executar, implementar e gerenciar as ações e projetos regulamentados no âmbito do aparelho jurídico-político do Estado.

Figura 1 - A reforma do Estado segundo o enfoque da administração pública gerencial

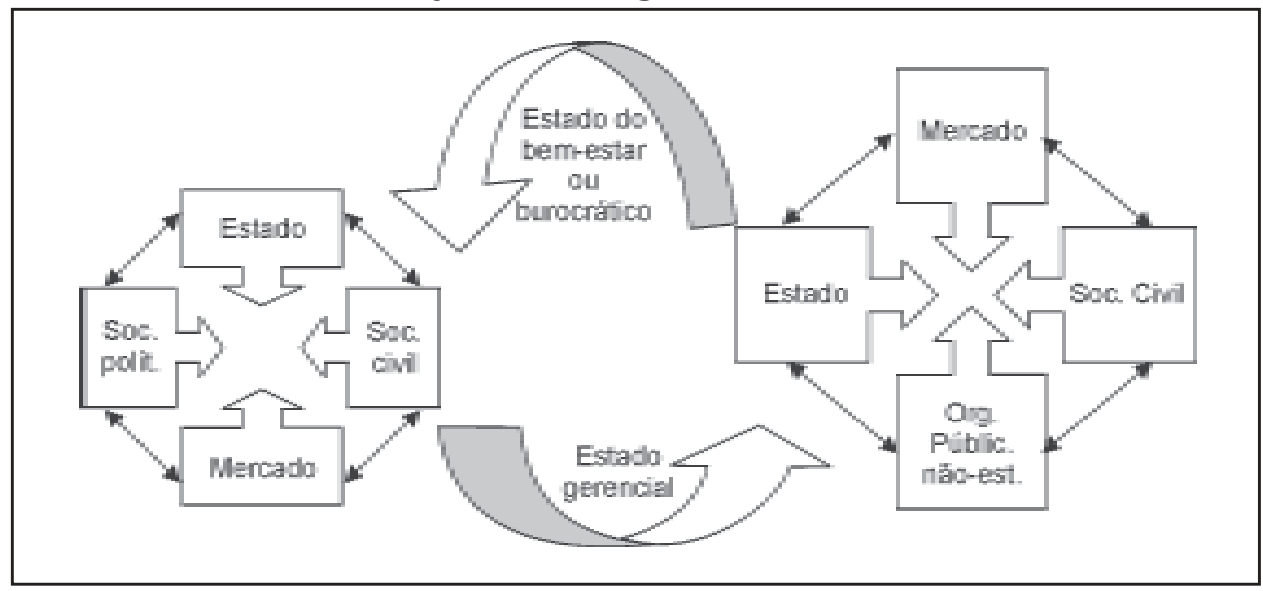

Fonte: Adaptação do autor a partir da leitura dos textos de Bresser Pereira $(1998,1999)$ 
O diagrama apresentado na Figura 1 evidencia a supressão do papel interventor tanto do Estado quanto de determinadas organizações corporativas (sindicatos, partidos políticos) situadas no âmbito da sociedade civil. Com isso, as organizações públicas não-estatais ${ }^{2}$ ganham maior visibilidade enquanto mecanismos de controle social e passam a cumprir uma função mediadora entre os interesses do mercado e a oferta de serviços públicos aos cidadãos-clientes, devendo o poder estatal incumbir-se do financiamento.

De acordo com esse desenho institucional, o mercado subtrai o papel dos poderes executivo, legislativo e judiciário, forçando assim a privatização do Estado e a eliminação da sua dimensão política, caracterizada pela participação e intervenção nas tomadas de decisões a respeito da vida em sociedade, assim como promove o enfraquecimento da ação estatal na oferta de serviços sociais de forma universalizada ${ }^{3}$.

Os princípios do Estado do futuro projetado por Bresser Pereira têm sido aplicados à realidade brasileira, especialmente nas gestões governamentais presididas por Fernando Henrique Cardoso ${ }^{4}$ (de 1995 a 1998; de 1999 até o momento atual). A propósito, Bresser Pereira foi Ministro da Administração e Reforma do Estado no primeiro mandato do presidente Fernando Henrique Cardoso, cujas propostas de reforma coadunam-se com as diretrizes indicadas pelo Fundo Monetário Internacional (FMI) e pelo Banco Mundial (BM).

\footnotetext{
No artigo denominado "Entre o Estado e o mercado: o público não-estatal", Bresser Pereira apresenta as organizações públicas não-estatais como uma das formas de mecanismo de controle destinadas a operar "na área de oferta de serviços de educação, saúde e cultura com financiamento do Estado". Segundo a definição por ele formulada, "o setor público não-estatal é também conhecido por 'terceiro setor', 'setor não-governamental' ou 'setor sem fins lucrativos'”. Em resumo, as organizações públicas não-estatais "são organizações ou formas de controle 'públicas' porque voltadas ao interesse geral; são 'não-estatais' porque não fazem parte do aparato do Estado, seja por não utilizarem servidores públicos, seja por não coincidirem com os agentes políticos tradicionais" (Bresser Pereira, 1999, p.).

3 Christina W. Andrews e Alexander Kouzmin, no artigo denominado "O discurso da nova administração pública", elaboram uma fulminante crítica ao modelo da administração pública gerencial formulado por Bresser Pereira. Do ponto de vista desses autores, "a nova administração pública se torna uma massa indiferenciada de idéias que são então moldadas em novos contornos: conservadores se tornam progressistas, neoliberais se tornam 'centro-esquerda', conflito ideológico se torna incapacidade cognitiva e assim por diante". Para eles, o novo discurso alardeado pelos neoconservadores "substitui a idéia do serviço público por uma de gerenciamento" (Andrews e Kouzmin, 1999, p. ).

4 Ao proferir o seu discurso de posse no dia $1^{\circ}$ de janeiro de 1995, FHC prometeu acabar com a miséria, assumindo como principal meta de seu governo a justiça social. Paradoxalmente, o seu mandato iniciou com a edição de Medidas Provisórias e Decretos que extinguiram os Ministérios do Bem-Estar Social e da Integração Regional, a Legião Brasileira de Assistência (LBA) e o Centro Brasileiro para a Infância e Adolescência (CBIA), o Conselho Superior de Defesa da Liberdade de Criação e Expressão e as Secretarias de Polícia Federal e de Trânsito. Para empreender o conjunto de reformas administrativas idealizadas pela nova presidência, "o apoio do Congresso, dos Estados e de todas as forças vivas da Nação" tornou-se essencial nesse processo de mudança. Nesse sentido, as "prioridades" assentavam-se em cinco pilares centrais: emprego, saúde, segurança, educação, produção de alimentos. Para alcançar tais propósitos, dever-se-ia em primeiro lugar cumprir a "missão" de desencadear "uma ampla reorganização da máquina do governo", dando um basta no "clientelismo, o corporativismo e a corrupção". O sentimento de "solidariedade" representava a "mola de um grande mutirão nacional, unindo o governo e a comunidade, para varrer do mapa do Brasil a fome e a miséria" (FHC exorta o povo a mudar o País, 1995, p. 5).
} 


\section{O modelo da administração pública gerencial e as suas repercussões nas unidades federadas: o caso do Pará}

Ao estudar a relação existente entre os partidos políticos e o governo no Brasil, Rachel Meneguello (1998) procura mostrar que os "partidos governamentalmente relevantes" possuem enorme influência/ingerência sobre as ações e decisões governamentais, mediante a participação na formulação e implementação das políticas apresentadas à sociedade, assim como interferem na estabilidade do gestor público. Quanto a esse aspecto em particular, a autora é enfática quando diz:

"Em linhas gerais, sobre a participação dos partidos nos governos, mostramos que há uma lógica condicionada pelas relações entre os poderes legislativo e executivo que exerce um importante impacto sobre a formação e a composição dos governos e sobre o desenvolvimento dos partidos que neles participam" (Meneguello, 1998, p. 37).

O estudo revela ainda que, no período de 1985 a 1997, as coalizões partidárias no governo federal foram compostas pelos principais partidos situados ao centro (PMDB e PSDB) e à direita (PFL e PTB), sendo que, a partir do ano de 1994, o PSDB começou a compartilhar o controle do governo, realizando uma coalizão partidária que em 1995 chegou a contar com o apoio de 18 estados brasileiros. Isso a leva a concluir que "os governadores exercem impacto sobre a organização do poder, através da formação de apoio e de influência sobre as bancadas parlamentares, de forma a atingir a dinâmica de formação das equipes ministeriais" (Meneguello, 1998, p. 74-77).

De acordo com as estatísticas oficiais mais recentes relativas à participação política da população brasileira, do Instituto Brasileiro de Geografia e Estatística (IBGE), cresceu o eleitorado no País, passando de 7,5 milhões em 1945 (16\% da população) para 106,1 milhões em 1998 (68\% da população). Embora o Brasil tenha se tornado o "quarto maior eleitorado do mundo", registra-se ainda um "alto número de votos inválidos (brancos e nulos) nas eleições brasileiras" (IBGE, 1999, p.). Além do mais, em que pese o processo de democratização do país pós-85, o quadro partidário brasileiro - especificamente após as eleições de 1998 - "organiza-se em torno de um número menor de partidos (PPB, PFL, PTB, PMDB, PSDB, PDT, PT e PSB), pelos quais se elegeram os governadores de estado, os senadores, o presidente e mais de $90 \%$ dos deputados eleitos" (IBGE, 1999, p.).

Os partidos de centro e de direita, tais como PSDB, PFL e PMDB, destacaram-se como partidos dominantes no cenário político. Seu poder pode ser observado considerando-se o resultado do processo elei- 
toral ocorrido em 1998, quando os candidatos indicados por aqueles partidos foram vitoriosos nas urnas. Na disputa pela presidência, por exemplo, o candidato Fernando Henrique Cardoso (PSDB) obteve 53\% das intenções de voto, enquanto, no segundo lugar, Luiz Inácio Lula da Silva (PT) recebeu 32\%. Para o cargo de Governador das unidades federadas, o PSDB preencheu $27 \%$ das vagas, o PFL foi contemplado com $22 \%$, o mesmo acontecendo com o PMDB que assegurou $22 \%$ das vagas. Os partidos de sustentação do governo federal garantiram, pois, $71 \%$ dos postos de gestores públicos. Quanto ao Senado, o PMDB elegeu $44 \%$ dos senadores, o PFL, $19 \%$ e o PSDB, 15\%. Assim, os partidos de centro-direita assumiram $78 \%$ da representatividade no Senado Federal (IBGE, 1999, p. 157).

No caso específico do Estado do Pará, o Senador Almir Gabriel (PSDB) foi eleito pela primeira vez governador no ano de 1994, passando a compor, a partir da sua posse em $1^{\circ}$ de janeiro de 1995, a equipe de coalizão partidária montada para dar sustentação político-institucional ao projeto de modernização do Estado brasileiro assentado nos pressupostos do modelo neoliberal ${ }^{5}$. A afinidade ideológico-partidária existente entre o novo governador paraense e Fernando Henrique Cardoso representava sem dúvida um dos elos de ligação que a partir daquele momento aproximaria as duas esferas governamentais em defesa do mesmo projeto social.

Quando Almir Gabriel tomou posse, o Estado estava mergulhado em uma dívida financeira "gigantesca", cuja estimativa naquela ocasião oscilava em torno de R $\$ 2$ bilhões e 360 milhões, que correspondiam a dívidas com a Justiça Comum e do Trabalho, dívidas contraídas junto a Bancos, empreiteiras, fornecedores e prestadores de serviços, dívidas com os servidores públicos e despesas emergenciais (DÍVIDA do Estado é gigantesca, 1995). Além das pressões sofridas pelo endividamento, havia o descontentamento do funcionalismo público estadual que reivindicava o pagamento do $13^{\circ}$ salário, bloqueado pela administração de Jáder Barbalho/Carlos Santos (1991-1994). A dívida do Pará era grande no campo social: em saúde, assistência, previdência, educação, cultura, segurança, habitação, emprego, nutrição. No setor econômico, também havia um "imenso" endividamen-

\footnotetext{
No estudo denominado "Banco Mundial: políticas e reformas", Maria Clara Couto Soares afirma que, a partir dos anos 90 , "o Brasil vem adotando uma série de reformas propostas pelo modelo liberal, sobretudo a partir do governo Collor. Implementou diversos programas de estabilização, cortou gastos públicos, renegociou a dívida externa, promoveu a abertura comercial, flexibilizou e estimulou o ingresso de capitais estrangeiros, deu início ao programa de privatização, eliminou diversos programas de incentivo e controle de preços, aumentou exportações, além de ter desmantelado os serviços e as políticas públicas" (Soares, 1996, p. 36).
} 
to afetando sobretudo o setor de estradas, energia, ciência e tecnologia, comércio, indústria.

Para superar essas adversidades, Almir prometeu, no seu discurso inaugural, "restituir a decência e a dignidade à administração pública". Segundo ele, o alcance de tais propósitos, porém, somente seria possível à medida que se concretizasse a inserção do Pará no "novo paradigma econômico do mundo... Desenvolver sem devastar é o novo rumo" (DÍVIDA do Estado é gigantesca, 1995).

O receituário apresentado para dar "decência à administração pública" abarcava uma combinação de medidas que precisavam ser tomadas o mais brevemente possível. Essas medidas visavam atacar os seguintes pontos de estrangulamento: aumento da arrecadação do Estado; redução da dívida estadual; eliminação do descontrole e do desmando na administração, equilibrando a receita e a despesa mediante um controle rígido dos gastos públicos; cortes no gasto com pessoal mediante a demissão de servidores públicos do Estado (SOLUÇÃO para $13^{\circ}$ só sexta-feira, 1995).

O "enxugamento da máquina estatal" representou o compromisso número um da nova administração, pois, mediante a adoção desse procedimento administrativo, o governador pretendia "extinguir o que é desnecessário na máquina estatal". Para atingir essa meta, seria necessário percorrer três caminhos indissociáveis: conciliar receita e despesa combatendo o funcionalismo por meio da exoneração de assessores e dos contratados a título de serviços prestados; arrumar a casa limitando o pagamento de diárias e horas extras; regularizar a situação financeira do Estado. Portanto, a redução das despesas compôs o item fundamental que norteou a instituição dos treze Decretos divulgados pelo secretário estadual de administração Carlos Jehá Kayath (ESTADO começa a demitir servidores, 1995), relativos ao gasto com pessoal.

Sobre o programa de redução dos gastos estaduais, as notícias jornalísticas veiculadas à época informavam:

"De uma só penada, o governador Almir Gabriel demitiu 400 assessores especiais e dispensou cerca de 5 mil pessoas que prestavam serviços ao Governo do Estado. É intenção do governador reduzir, até o início da próxima semana, em pelo menos 50\% o número de $35 \mathrm{mil}$ servidores temporários"(ALMIR começa demitindo 5 mil, 1995).

A "caça às bruxas" promovida pelo gestor estadual incluiu também o combate aos "marajás", especialmente aqueles que estavam encostados na Vice-Governadoria, denominada de "fantasmagórica", pois, segundo o próprio Vice-Governador, "oficialmente ela não exis- 
tia, mas havia gente lotada nela". Essa situação deixava a máquina estadual "inchada" e com dificuldades para racionalizar os seus gastos financeiros. De acordo com o diagnóstico apresentado por Hélio Gueiros Júnior.

"O inchaço maior está localizado na SEDUC (Secretaria de Estado de Educação) e na SESMA (Secretaria de Estado de Saúde Pública). É preciso esclarecer uma coisa. Há órgãos onde existem mais servidores temporários, como a FUNTELPA (Fundação de Telecomunicações do Pará), do que efetivos. Mas nem por isso se deve paralisar o serviço da FUNTELPA. Na SEDUC existem 26 mil temporários" (GOVERNO descobre "marajás", 1995).

A batalha em favor da reconstrução do Estado do Pará implicava, portanto, a redução da participação estatal nos gastos públicos. O programa de demissões era encarado por Almir Gabriel como um antídoto eficaz para a eliminação do inchaço da administração estatal. Isso fica muito evidente no depoimento prestado à imprensa local, quando ele afirmou: "O nosso objetivo é trazer o Estado para o tamanho que ele precisa ter para atender às necessidades da população" (ALMIR pode demitir até 15 mil, 1995).

Quais eram os pilares centrais escolhidos por Almir Gabriel a fim de edificar as novas "Bases da construção do Novo Pará?"

Ao prestar conta do andamento de seu governo na "Mensagem do Governo do Pará à Assembléia Legislativa - 1999", Almir Gabriel expôs a sua preocupação com a "recondução da ação pública", dizendo que a concretização de tal objetivo exigiria

"sacrifícios a todos e, acima de tudo, o rompimento definitivo com a prática do desperdício, do clientelismo e da complacência com os interesses corporativistas e patrimonialistas, culturas tão presentes que impregnaram a formação do Estado brasileiro e, particularmente, tão marcantes na história paraense" (GABRIEL, 1999, p. 12).

A "racionalidade" e a "eficiência" foram medidas tomadas com o propósito de revitalizar a Receita Estadual. Como parte desse programa, houve uma reestruturação nos gastos governamentais, com a inclusão de três "medidas emergenciais": ajustes na folha com pessoal; redução do efetivo de 11.884 servidores temporários e cortes na concessão de diárias e outros artifícios de remuneração indevida; exclusão de gastos com 2.300 servidores fantasmas. Além dessas ações, o governador paraense procurou também obter o controle das dívidas esta- 
duais, empenhando-se especialmente na "renegociação, para o prazo de 30 anos, da dívida pactuada com a União" (GABRIEL, 1999, p. 14). Este foi o caminho percorrido para retomar a credibilidade da administração pública do Pará na captação de recursos provenientes do Governo Federal assim como dos organismos financiadores nacionais e internacionais.

Era necessário, portanto, atribuir um novo papel ao Estado do Pará, reformando-o e modernizando as suas estruturas político-administrativas. Nessa perspectiva, o governador Almir Gabriel justificava a sua intervenção dizendo:

"A reforma e a modernização do Estado, com o objetivo de aumentar sua eficiência, fortalecer os instrumentos de gestão e consolidar as bases da cidadania, determinaram a redefinição das competências entre as esferas de governo e a reorganização do aparelho estatal, exigindo fortes mecanismos de redução de despesas e ajuste fiscal, bem como a revisão do próprio papel do Estado, levando-o à privatização de setores básicos para o desenvolvimento econômico, como os de energia, comunicação, transporte e dos tradicionais empreendimentos estatais, especialmente localizados na produção de bens intermediários e capital, como alternativa para renovar o fluxo de investimentos nessas áreas e captar recursos para financiar os gastos sociais" (GABRIEL, 1999, p. 23).

Para concretizar as metas acima propostas, tornava-se necessário concentrar os investimentos estaduais naqueles setores com possibilidades de exploração econômica. Desse modo, as "bases" utilizadas para a reconstrução do Pará priorizaram dois campos de atuação: a) a formação de um parque produtivo com considerável grau de diversificação; b) o redirecionamento da ação do Estado no intuito de construir um projeto de desenvolvimento que se adequasse a esse contexto de transformação e que, ao mesmo tempo, respondesse, de forma urgente e inventiva, ao dilema da criação de emprego e renda (GABRIEL, 1999, p. 23).

No entendimento do então governador, esse conjunto de medidas deveria culminar com

"a consolidação de um desenvolvimento com justiça social, no qual, e por isso mesmo, a condição de cidadania do povo paraense fosse o horizonte prevalecente (...) tais compromissos, em termos práticos, assinalam para um cenário configurado pela geração dinâmica de empregos, associada à justa distribuição de renda e ao suprimento, com efici- 
ência e eficácia, de serviços básicos como educação, saúde, segurança, etc." (GABRIEL, 1999, p.).

Havia, entretanto, alguns "dilemas" que desafiavam o projeto governamental idealizado por Almir Gabriel: 1) o predomínio de uma estrutura extrativista que se chocava com o novo perfil da economia mundial decorrente do comportamento globalizador dos mercados; 2) o avançado sucateamento do aparelho do Estado e o esgotamento de sua capacidade de intervenção; 3) a desmotivação da sociedade acerca da construção de um projeto paraense de âmbito coletivo. Assim, os compromissos governamentais precisavam voltar-se para duas questões prioritárias, envolvendo, de um lado, a mobilização social pela transformação e diversificação da base produtiva do Estado mediante o estímulo aos setores produtivos como a agroindústria, a verticalização mineral e o turismo; de outro, o empenho na consolidação de uma base infra-estrutural de integração por meio do investimento em infra-estrutura nos setores de energia, transporte, saneamento e habitação (GABRIEL, 1999, p. 24).

Os esforços do governador paraense convergiram para um modelo de Estado que deveria ser utilizado como "instrumento do interesse coletivo". O Estado estava submetido à lógica de mercado, convertendo-se num "prestador de serviços básicos à população". Daí a razão pela qual Almir Gabriel assumiu como diretrizes do "Novo Estado do Pará" "tanto um rigoroso critério de prioridade de gastos público, quanto a reestruturação e a democratização operativa da gestão na busca de eficiência e eliminação de desperdícios" (GABRIEL, 1999, p. 36).

Para organizar o processo institucional de enxugamento da intervenção estatal, o governo estadual colocou em funcionamento o Programa Estadual de Desestatização (PED), que visava "não só a reavaliação do desempenho do Estado em áreas de atuação concorrente com a iniciativa privada, como a redefinição do modelo de gestão em vários setores governamentais" (GABRIEL, 1999, p. 37).

Com o objetivo de fiscalizar o andamento do processo de privatização, também foi criada a Agência Estadual de Regulação e Controle dos Serviços Públicos (ARCON), que tem como uma de suas funções básicas "dar conta da fiscalização da prestação e da qualidade dos serviços ofertados pelas empresas do setor energético, bem como de outros serviços públicos onde vier a se estabelecer a iniciativa privada" (GABRIEL, 1999, p. 38).

No que concerne ao modelo de gestão pública proposto por Almir Gabriel, a atenção governamental voltou-se para duas estratégias imprescindíveis: 1) formar grupos de atuação integrada de órgãos gover- 
namentais afins, de modo a promover a necessária articulação interinstitucional, possibilitando, assim, a contenção de despesas e a ampliação de investimentos; 2) implementar o processo de reestruturação de gestão nos setores essenciais como saúde, educação e segurança (GABRIEL, 1999, p. 38).

No caso mais específico das áreas de saúde e educação, além da descentralização gerencial que sofreram, esses setores foram submetidos a um acelerado processo de municipalização, que, em tese, permitiria democratizar e racionalizar a gestão desses serviços nas circunscrições territoriais dos vários municípios.

Em síntese, as bases sustentadoras do novo Estado proposto por Almir Gabriel estariam fixadas nos seguintes alicerces: a) gestão dos meios: alicerce do Estado Público; b) gestão de parceria com os Municípios; c) investimentos infra-estruturais estratégicos: a base do Novo Pará; d) revitalização da economia: a semente da transformação da base produtiva; e) construção do suporte de uma nova indústria: o turismo (GABRIEL, 1999, p. 28-73).

Nesse processo de redefinição do campo de atuação do poder público, o setor educacional encontra-se profundamente afetado, sofrendo, portanto, os condicionamentos das ações desencadeadas pelo governo paraense. É para essa questão que passarei a voltar a atenção na seção subseqüente.

\section{A implementação da administração pública gerencial no campo educacional: em busca de um ensino de qualidade}

Para entender os impactos da administração pública gerencial no campo educacional, recorrerei ao Plano Estadual de Educação nas suas versões 1995-19996 e 1999-2003, no intuito de poder identificar o conjunto de ações e metas definidas pelo governo estadual paraense e os efeitos que elas estão produzindo nessa área.

O Plano Estadual de Educação representa uma diretriz estabelecida pelo governo estadual a fim de viabilizar a consolidação do Plano Decenal de Educação para Todos, veiculado pelo governo federal em

\footnotetext{
A análise relativa ao Plano Estadual de Educação - 1995-1999 constitui uma versão reformulada de parte do texto da Dissertação de Mestrado defendida por mim no ano de 1997, com o título As políticas educacionais para o ensino médio no Pará: uma análise histórica (1964-1982) (Corrêa, 1997). No capítulo IV, especificamente, destino um espaço à reflexão acerca das "Estratégias de interferência do Estado no campo da educação: os desafios das atuais políticas públicas e a persistência da problemática social do Ensino Médio". Nesse capítulo, focalizo o Plano Estadual de Educação do Pará (1995-1999) como um documento por meio do qual o Governo paraense à época (primeira gestão Almir Gabriel) estabelece vínculos institucionais com as políticas neoliberais no campo da educação.
} 
1990. Na realidade paraense, a formulação daquele Plano resultou de uma série de encontros, seminários, conferências, reuniões técnicas, fóruns estaduais e internacionais e debates, os quais se iniciaram no ano de 1990 e se estenderam até 1994, quando da realização da Conferência Estadual de Educação para Todos.

As metas fixadas no Plano de Educação expostas logo na sua apresentação à sociedade consistem na "superação da desigualdade social (...) ampliar o acesso à educação pública e, por esta via, garantir a integração dos cidadãos à sociedade e a promoção social dos mesmos". Outra preocupação está voltada para "acompanhar passo a passo as ações a serem dadas no sentido da superação das dificuldades do sistema educacional, bem como a aplicação dos recursos públicos vinculados a este compromisso social" (SEDUC, 1995).

Prioritariamente, de acordo com o discurso governamental, o Plano de Educação envidaria esforços para oferecer às crianças, aos jovens e aos adultos oportunidades educativas com qualidade que lhes permitam obter um nível satisfatório de aprendizagem. A concretização de tais objetivos, contudo, condicionava-se à solução de duas questões básicas: "a persistência de um elevado déficit escolar, assim como das taxas de evasão, reprovação e, conseqüentemente, de repetência"; a "obrigatoriedade do poder público garantir a todos, em igualdade de condições, o acesso e a permanência na escola, assim como a gratuidade desse nível de ensino com base num padrão de qualidade adequado" (SEDUC, 1995).

Além das preocupações registradas acima, algumas condições precisariam ser observadas, entre as quais se destacam:

"Continuidade das políticas educacionais; política de comprometimento com as questões do magistério; adoção de práticas sistemáticas e adequadas de avaliação dos programas, projetos e sistemas a implantar ou já em curso; descentralização das ações a nível de municípios e de sub-regiões do Estado; existência de recursos financeiros em volume suficiente para atender as necessidades referentes à construção de mais salas de aula; continuidade e mesmo intensificação do processo de municipalização do ensino" (SEDUC, 1995, p. 2).

No que diz respeito à continuidade das políticas educacionais, a reeleição de Almir Gabriel em 1998 possibilitou-lhe a permanência de suas ações no sentido de dar prosseguimento às mudanças por ele alavancadas no setor da educação. Por outro lado, a municipalização do ensino tornou-se muito mais intensiva nos municípios do Pará, abrangendo em 1998 um total de 45 municípios.

Segundo os argumentos explicitados no Plano Estadual de Educação, a ação do poder público municipal tornou-se um elemento essenci- 
al para o aumento do número de vagas na faixa do ensino fundamental. Essa interferência reforça consideravelmente a tese de que "o município passe progressivamente a se responsabilizar exclusivamente pelo Ensino Fundamental". No que concerne ao $1^{\circ} \mathrm{grau}$, "a prioridade não é mais a expansão da rede escolar, mas a introdução de esforços visando à melhoria da qualidade de ensino nesse nível" (SEDUC, 1995, p. 8-9).

Quanto ao ensino de $2^{\circ}$ grau, o documento da Secretaria de Estado de Educação revela a existência de uma "falta de investimentos expressivos". Muito embora seja constatada essa escassez de recursos, é notório que "a demanda pelo $2^{\circ}$ Grau vem crescendo significativamente nos centros urbanos, pressionando enormemente este nível de ensino, que vem se expandindo sem as condições minimamente necessárias". De acordo com as previsões dessa instituição, a rede estadual somente poderá "aumentar substancialmente a sua participação, à medida que for ocorrendo a atuação progressiva do município na absorção do $1^{\circ}$ Grau" (SEDUC, 1995, p. 9-10)).

No que se refere à questão da eficiência e produtividade escolar, pode-se perceber que o ingresso do aluno no sistema escolar público do Pará está marcado por acentuado descompasso no nível econômico. Isso significa que o aprendiz "em decorrência da faixa de renda em que se encontra a sua família, e até mesmo pela necessidade de também contribuir economicamente para a sobrevivência mesma, se vê obrigado a trabalhar, quando deveria se dedicar exclusivamente à escola" (SEDUC, 1995, p. 11-12). Esse fato evidencia-se mais freqüentemente nas áreas rurais, especialmente porque nelas

"o ensino é de baixa qualidade, devido à existência de professores leigos e não remunerados adequadamente, a salas de aula com alunos de séries diferentes que são atendidos no mesmo horário escolar (turmas multisseriadas, para as quais não se desenvolveu e implantou ainda uma metodologia adequada de tratamento pedagógico), à falta de material didático e até mesmo de merenda escolar" (SEDUC, 1995).

Uma vez diagnosticadas essas distorções, encontramos no Plano Estadual um pronunciamento bastante incisivo indicando que o sistema escolar continua operando com "um alto índice de reprovação na $1^{\mathrm{a}}$ série do $1^{\circ} \mathrm{Grau}$, onde se percebe a existência de um desnível crítico entre os (alunos) que entram e os que conseguem concluir o $1^{\circ} \mathrm{Grau}$ dentro do prazo previsto, em uma proporção de 100 alunos que entram na $1^{\mathrm{a}}$ série do $1^{\circ}$ Grau para 8 alunos que conseguem concluir" (SEDUC, 1995, p. 13). 
O Plano Estadual de Educação considera que "é deficiente o ensino no interior do Estado". Embora a realidade dos municípios revele esse cenário constrangedor, o documento em análise alerta: "a partir de 1994 a rede municipal ultrapassou a rede estadual, pela ação dos atuais prefeitos na construção de novas escolas, nos dois primeiros anos dos seus mandatos". Essa interferência serviu como um dos motivos para reforçar o argumento em favor do processo de municipalização do ensino no contexto paraense, pois esta "está ocorrendo de forma acelerada" (SEDUC, 1995, p. 14-15).

Esse documento prevê igualmente a formulação de programas de assistência ao educando com o intuito de contribuir para o "desenvolvimento do setor educacional". Tais programas abrangem: "concessão de bolsas de estudo através da aquisição de vagas na rede particular de ensino; aquisição de material de cozinha, cantina e gêneros alimentícios; aquisição de material escolar; e transporte e armazenamento dos gêneros alimentícios e material escolar" (SEDUC, 1995, p. 23-24). Apesar do esforço que até o momento tem sido feito pelo Estado, tais ações "têm apresentado pouca eficácia" em termos da produtividade do ensino.

Por meio das iniciativas tomadas, a Secretaria de Estado de Educação procura tornar mais eficiente sua atuação. Para tanto, pretende ir "gradativamente, assumindo a função que lhe é fundamental - definir, coordenar, assessorar e fiscalizar a execução das políticas educacionais em curso para a área" (SEDUC, 1995, p. 26). Nesse processo, compete aos Municípios o papel de unidades executoras dos planos e programas oficiais.

Encontram-se contemplados também no Plano de Educação aqueles aspectos concernentes aos problemas de pessoal e de gestão do sistema. Quanto ao item relativo a pessoal, o documento revela a presença de "um desestímulo e uma visível perda de auto-estima dos servidores da educação face aos baixos salários da categoria" (SEDUC, 1995, p. 27-28). Registra-se ainda uma preocupação com o

"(...) elevado número de professores leigos (em 1994 55, 1\% dos professores da zona urbana vinculados à educação infantil não eram titulados, enquanto essa situação se agrava quando se toma como referência os professores da zona rural, cujo índice chega a atingir 82, 7\% nesse mesmo ano); a inexistência de professores para determinadas disciplinas no interior do Estado; reduzidos programas de capacitação de pessoal; baixa participação do corpo funcional e da comunidade na vida da escola; e exigüidade de recursos e de materiais pedagógicos para a preparação de aulas" (SEDUC, 1995). 
Uma outra situação mencionada no Plano e considerada um problema grave diz respeito ao "elevado número de servidores temporários no quadro de pessoal da Secretaria Estadual de Educação e cultura" (SEDUC, 1995, p. 28-30). Esse inchaço institucional serviu como uma das justificativas para se fazer o corte nos gastos com pessoal, em especial aqueles vinculados ao serviço público mediante contratos temporários.

Entre os problemas de gestão do sistema, aqueles que apresentam maior gravidade são:

"falta de um sistema geral de protocolo informatizado e ágil; falta de elementos legais, normativos e de instrumentos outros indispensáveis à descentralização regional das ações e à autonomia das escolas (Manuais, Regimentos Escolares, Conselhos Escolares, Portarias, etc.); inexistência de diagnósticos precisos sobre a situação de cada unidade escolar; acompanhamento deficiente de obras realizadas nas escolas; falta de projetos pedagógicos; relação deteriorada entre escola e comunidade; exigüidade ou até inexistência de materiais didáticos como bibliotecas e outros; e número significativo de escolas e cursos não regularizados" (SEDUC, 1995).

Uma vez expostas as dificuldades relativas ao gerenciamento do sistema escolar, o Plano Estadual de Educação passa a abordar a disponibilidade de recursos financeiros. O fato de ser muito ampla a esfera de abrangência da Secretaria Estadual de Educação e Cultura faz com que "a quase totalidade dos seus recursos sejam direcionados para despesas com pessoal, pouco restando para desenvolvimento de recursos humanos (capacitação e reciclagem dos professores e pessoal técnicoadministrativo), construção e recuperação de escolas, aquisição de equipamentos e outros custeios". Assim, "intensificar a municipalização do ensino" representa a única saída racional e eficiente capaz de permitir à administração estadual superar o congestionamento em que se encontra, de modo a poder "investir mais expressivamente na expansão do ensino de $2^{\circ}$ Grau" (SEDUC, 1995, p. 31-32).

Partindo dessas alarmantes constatações, o Plano de Educação diz que "é praticamente irrisório o montante destinado a investimentos e às demais despesas de custeio da educação". Mas esse "quadro de deficiência aguda" deverá ser superado com a adoção de algumas "linhas de atuação" tendo em vista "à melhoria das condições de custeio bem como o de inverter o perfil dos gastos, baseando-se no princípio de que, se não é possível aumentar a curto prazo o volume de recursos, deve-se potencializar sua aplicação" (SEDUC, 1995, p. 33). 
Foi justamente por isso que se instituíram as diretrizes básicas para a melhoria do ensino no Pará, que reafirmam a necessidade da "continuidade nos projetos comprovadamente eficazes mesmo com mudanças nos quadros diretivos da Secretaria ou governamentais (...) através da participação da sociedade com base na descentralização das ações" (SEDUC, 1995, p. 34-41). Respaldadas nesses princípios, delinearamse as seguintes diretrizes:

"(...) deverá ser transferida de forma gradual para a administração dos municípios a gerência do ensino de $1^{\circ}$ Grau; investir na melhoria da qualidade do Ensino Fundamental; intensificar o processo de municipalização da merenda escolar e da aquisição do livro didático; na área de abrangência do ensino de $2^{\circ}$ Grau, adotar uma nova filosofia quanto às escolas profissionalizante tornando-as centros de produção que oportunizem o ingresso dos alunos no mercado de trabalho; integração escola-comunidade; descentralizar praticamente todos os procedimentos administrativos, financeiros e até mesmo pedagógicos, transferindo para a órbita das Unidades Regionais de Ensino (URES) e das Escolas-Sede decisões administrativas que estão totalmente concentradas no Órgão-Sede; Política de valorização dos servidores do magistério; investir na melhoria e na recuperação da rede física; investir na qualidade e na produtividade da educação pela modernização da estrutura técnico-administrativa e pela otimização dos recursos financeiros; viabilização da gestão democrática na escola; incentivar a informática educativa; aumentar a comunicação entre todos os segmentos do sistema, através de recursos de telecomunicações (viabilizados pelos projetos: Telecurso 2.000, Um Salto para o Futuro, TV-Escola, TV-SEDUC, e Vídeo-Escola)" (SEDUC, 1995).

No Plano Estadual de Educação, está prevista também a aplicação de programas estratégicos para o desenvolvimento do setor educacional. São seis os programas que deverão concorrer para esse fim (os textos entre aspas que seguem provêm de SEDUC, 1995, p. 43-59):

1. Redução do déficit educacional, por meio de "ações voltadas para a melhoria dos espaços físicos que garantam a oferta de novas vagas na escola pública, onde as ações básicas devem visar a construção, aparelhamento, ampliação e recuperação das unidades escolares existentes no Estado".

2. Melhoria da qualidade do ensino, mediante a "redução dos índices de reprovação e repetência, na melhoria das condições em que se dá a aprendizagem e no aprofundamento dos conteúdos programáticos ministrados". Aqui as ações básicas dirigem-se para a confecção de cartei- 
ras, manutenção do projeto Gavião para a conclusão de formação de professores leigos na zona rural até 1999; manutenção do Sistema Modular de Ensino para o $2^{\circ}$ Grau; implantação de 69 telepostos no interior (Ensino à Distância); construção de Núcleos Avançados de Ensino Supletivo no interior; expansão do projeto Um Salto para o Futuro; aquisição de vagas em escolas da rede particular de ensino para suprir a falta de vagas na rede pública; (...) incentivo à informática educativa; capacitação de pessoal voltado para as séries iniciais; qualificação de professores de $1^{\mathrm{a}}$ série do Ensino Fundamental da rede de ensino oficial do interior e da capital; assessoramento técnico-pedagógico, acompanhamento e fiscalização permanentes e atendimento às escolas em regime de convênio; implementação e intensificação do Programa de Educação à Distância.

3. Direcionamento do ensino para vocações econômicas do Estado, programa que visa redefinir, equipar, recuperar e implementar as Escolas Técnicas, Agrotécnicas e Agropecuárias existentes ou em fase de construção, assim como implantar e implementar cinco novas Escolas Técnicas Educacionais; e reorientar os demais cursos profissionalizantes. As ações básicas terão como prioridade a implementação e o aparelhamento das Escolas Técnicas, Agrotécnicas, Agroindustriais e Agrícolas e redirecioná-las de acordo com as potencialidades socioeconômicas e as necessidades do mercado, mediante a devida adequação dos currículos a esses objetivos; construção e aparelhamento de novos Centros de Formação Profissionalizante; e adequação dos cursos de $2^{\circ}$ grau que conferem habilitações com o propósito de "rever currículos e adequá-los às necessidades do mercado".

4. Integração escola-comunidade, programa que, por sua vez, visa "romper a relação deteriorada e hostil entre a escola e a comunidade". As ações básicas a serem desencadeadas devem voltar-se para "construção de barracões de uso múltiplo para utilização em atividades educacionais e comunitárias, construção de quadras de esporte; aparelhamento das escolas estaduais; implementação, expansão e manutenção de Pólos Esportivos; realização de eventos de lazer e desportos; e atendimento a alunos através do Programa Nacional de Alfabetização e Cidadania".

5. Descentralização e municipalização das atividades educacionais, programa cujo objetivo consiste em "implementar as bases físicas e organizacionais necessárias à descentralização e à municipalização da administração da educação no Estado, as decisões e ações relativas à administração da educação". Para a consecução desse programa, as ações básicas contemplam: "aparelhamento e reestruturação das Unidades 
Regionais de Ensino e Escolas-Sede; qualificação da mão-de-obra necessária à implementação do novo modelo administrativo; transformação e aparelhamento do Centro de Treinamento de Recursos Humanos em Centro de Formação do Servidor da Educação; implementação de ações na área da saúde preventiva e curativa, acidente de trabalho e doenças profissionais; manutenção das escolas através da chegada de recursos para serem administrados diretamente pelas mesmas; e informatização de todos os pólos administrativos da Secretaria de Estado de Educação".

6. Gerenciamento administrativo do setor educacional, programa voltado para a "manutenção das atividades administrativas ocorrentes em todos os setores operacionais da Secretaria de Estado de Educação". As ações básicas nele previstas visam a: "modernização do sistema de lotação de professores e demais servidores; manutenção das despesas operacionais e da folha de pagamentos e encargos sociais dos funcionários da Secretaria; (...) descentralização do controle dos bens móveis e imóveis do Estado; melhoria dos níveis salariais; recrutamento de professores concursados e de temporários; abertura de concurso público; manutenção do Conselho Estadual de Educação; (...) realização das estatísticas educacionais; implantação de um aparelho de TV, um videocassete e uma antena parabólica em cada uma das escolas do Estado com mais de 1000 alunos; criação da TV SEDUC para interação diária do órgão central com as escolas; e criação do programa de rádio com o propósito de suprir a deficiência de comunicação entre a sede e as inúmeras escolas que integram o sistema".

Examinando-se os argumentos que fundamentam o novo documento divulgado pela Secretaria de Estado de Educação, intitulado Municipalização do ensino fundamental no Pará, constata-se que esse novo documento defende uma maior "integração das redes escolares do ensino fundamental". Por isso, "a municipalização do Ensino Fundamental no Pará (...) se impõe como uma necessidade à melhoria da qualidade da educação no Estado" (SEDUC, 1996, p. 17).

Ao procurar esclarecer o processo de municipalização, o texto acima mencionado diz:

"é importante que a municipalização não seja entendida simplesmente como uma mera transferência de responsabilidade do Estado para os municípios. Ela é, antes de tudo, uma clara definição de áreas de atuação e competência na gestão da educação, na busca de soluções para problemas comuns e locais. É o estabelecimento de parcerias entre esferas governamentais diferentes com vistas a beneficiar a população que deve freqüentar a escola. É o compromisso de administração conjunta do ensino básico" (SEDUC, 1996, p. 21). 
Esse documento estabelece o período de quatro (4) anos para que o processo de municipalização se efetive na realidade paraense, iniciandose em 1996 e prolongando-se até 1999. A primeira etapa consiste na "transferência da gerência do pré-escolar e do $1^{\circ}$ Grau Menor ( $1^{\mathrm{a}}$ a $4^{\mathrm{a}}$ série) que ainda estão sob a responsabilidade da rede estadual"; o segundo momento atingirá as "escolas que possuem a $1^{\mathrm{a}}$ a $4^{\mathrm{a}}$ série de forma associada à $5^{\mathrm{a}}$ a $8^{\mathrm{a}}$ série e/ou ao pré-escolar, independente ou não de estarem associadas ao $2^{\circ} \mathrm{Grau}$ "; posteriormente, a ação concentrar-se-á naquelas "escolas que funcionam com turmas exclusivas de $5^{\mathrm{a}}$ a $8^{\mathrm{a}}$ série, de forma associada ou não ao $2^{\circ}$ Grau" (SEDUC, 1996, p. 26-28).

Enquanto estratégia a ser adotada para viabilizar o desenvolvimento do processo de municipalização, a Secretaria de Estado de Educação atenderá com prioridade

"aqueles municípios que mostrem interesse imediato, aqueles que no contexto regional se constituem em modelos de referência socioeconômica para os demais municípios, e aqueles cujo total de escolas a serem municipalizadas não exceda o máximo de 10, já que neste caso encontra-se mais da metade dos que estão listados nesta primeira fase da municipalização" (SEDUC, 1996, p. 38-39).

A análise das informações relatadas no Plano Estadual de Educação tornou evidente que o Estado do Pará vem tentando reestruturar seu sistema de ensino de modo a imprimir-lhe maior eficiência e produtividade dadas as exigências das políticas neoliberais adotadas no Brasil por grande parte das administrações públicas estaduais e municipais. Essa medida constitui uma opção estratégica para coibir e eliminar os excessos cometidos pela prática de políticas clientelísticas e centralizadoras que até o momento figuram no espaço educacional paraense, provocando o congestionamento do sistema e comprometendo a exeqüibilidade das ações previstas nas propostas governamentais.

Desse modo, podemos dizer que o conjunto das ações previstas converge para aquelas exigências feitas pelo governo federal, que induz as unidades federadas a assumir com a máxima prioridade a oferta do ensino na modalidade de $2^{\circ}$ grau. No caso específico do Pará, o alcance dessas metas encontra-se condicionado à realização de estratégias oriundas do modelo de administração pública gerencial, no qual o atendimento do ensino fundamental constitui uma condição indispensável ao sucesso desse empreendimento.

Portanto, na concepção da Secretaria Estadual de Educação, o acúmulo de competências atualmente assumidas pelo Estado implica a não 
execução de modo satisfatório das políticas públicas voltadas para o campo da educação. Esta necessita interligar-se às novas tendências anunciadas pelo processo de desenvolvimento industrial, o qual requer maior adequação da esfera educacional ao setor produtivo. Seguindo esses mandamentos, o Pará poderá supostamente fortalecer suas ações quanto ao ensino de nível médio no intuito de adequar seus cursos e currículos a uma formação direcionada para a satisfação das exigências empresariais.

Como podemos observar, a tônica de ambos os documentos veiculados pela Secretaria de Educação é a municipalização como o ponto medular do qual depende a funcionalidade do sistema escolar bem como a viabilidade dos gastos previstos para esse setor.

Por meio da difusão de um discurso de valorização da composição de um "Estado mínimo", a lógica neoliberal advoga a necessidade de "reduzir" ao máximo a abrangência da ação do Estado, de modo a torná-lo mais dinâmico em todos os setores produtivos mediante o estímulo à interferência da iniciativa privada na condução do projeto de modernização econômica. No campo educacional, por exemplo, isso se justificativa pela busca de eficiência do sistema escolar.

O fato de o Estado deixar de conceder gratuitamente serviços sociais, como educação e saúde, abre espaço para que as organizações públicas não-estatais intercedam no oferecimento dessas políticas. No caso do Pará, alguns projetos já estão sendo colocados em prática com esse perfil institucional.

- O projeto "O LIBERAL na Escola", criado no ano de 1994 pelas Organizações Rômulo Maiorana, visa "cultivar o hábito da leitura entre alunos de $5^{\mathrm{a}}$ a $8^{\mathrm{a}}$ série do ensino fundamental e na faixa etária de 8 a 14 anos" (ALUNOS do "Rego Barros" se entusiasmam com a notícia, 2000, p. 5).

- O projeto "Riacho Doce", criado em 1993, atende crianças e adolescentes na idade dos 7 a 14 anos. Mantido pela Universidade Federal do Pará, pelo Instituto Ayrton Senna, pelo Indesp e pelo BNDES, é "uma proposta acadêmico-social que oferece esportes, atividades pedagógicas, agrícolas e atendimento médico e odontológico, além de complemento alimentar e acompanhamento psicossocial" (PROJETO ajuda crianças ligadas ao Riacho Doce, 2000, p. 5).

- O projeto "Criança Vida", lançado em 31 de março de 2000, faz parte do novo modelo de gerenciamento segundo o qual as empresas procuram destacar-se também pela sua face "socialmente responsável" e solidária. O projeto tem dois objeti- 
vos iniciais: 1) aumentar a capacidade da UTI neonatal da Santa Casa de Misericórdia do Pará e 2) implementar um programa de atendimento às mães adolescentes da Santa Casa (NO rumo da responsabilidade social, 2000, p. 5). Esse projeto conta com a participação de empresários donos de lojas e supermercados, de estabelecimentos de ensino, e com o patrocínio do Banco da Amazônia (BASA) e da co-participação da Rede Celpa (companhia de energia elétrica recentemente privatizada).

Dando continuidade aos programas implementados durante a primeira gestão de Almir Gabriel à frente do governo paraense, o Plano Estadual de Educação - 1999-2003, logo na apresentação do documento à sociedade, postula a necessidade de "conceber novas ações de gestão pública que possibilite ao estado do Pará, no limiar do novo século em formação, a conquista de um ensino de qualidade para todos" (SEDUC, 1999).

Com o estabelecimento desse novo Plano de Educação, o governo evidencia a sua intenção de "consolidar processos iniciados mas não ainda concluídos, como a municipalização do ensino fundamental", preocupando-se especificamente com as "mudanças estruturais que estão se processando no setor no momento atual" (SEDUC, 1999). Eis aí o "compromisso social" assumido pelo governo do Estado em favor da educação pública!

As metas e ações delineadas para o campo educacional nesse documento indicam a necessidade de se operar modificações em três aspectos essenciais que se converteram na base de sustentação do sistema de ensino idealizado para produzir uma educação de qualidade. São eles: 1) readequação da estrutura curricular das escolas públicas; 2) urgente fortalecimento do regime de colaboração do ensino público; 3) reforma do ensino médio e profissional.

Um dos maiores desafios lançados durante a gestão de Almir Gabriel foi a insistente luta em favor da "melhoria da qualidade do ensino". Para tanto, a Secretaria de Educação adotou alguns mecanismos capazes de viabilizar tal intento: a) a adoção de programas de capacitação de professores; b) o programa de aceleração da aprendizagem; c) a redução sistemática do déficit educacional por meio da implantação, em 1997, do Fundo de Manutenção e Desenvolvimento do Ensino Fundamental e de Valorização do Magistério (FUNDEF). Com a instituição dessas medidas, o governo do Pará espera implementar uma "pedagogia da qualidade" junto ao sistema público de ensino (SEDUC, 1999, p. 9-12). 
No presente Plano de Educação, a "manutenção e a continuidade de políticas públicas" são destacadas como condições fundamentais a fim de se atingir a almejada qualidade no campo educacional, pois, conforme ressalta o referido documento, "o que tem na verdade impedido que a educação no Pará alcance níveis mais elevados de qualidade é a descontinuidade das políticas públicas pertinentes ao setor educacional" (SEDUC, 1999, p. 12). Do ponto de vista oficial, essa descontinuidade implicou uma "década perdida" na área da educação (1988-1998).

De acordo com os argumentos utilizados no recente Plano Estadual de Educação, a solução para o problema da oferta de um ensino de qualidade na unidade federada paraense passa pela adoção das seguintes medidas: 1) gestão escolar compartilhada com a comunidade (eleição do conselho escolar; eleição da direção da escola); 2) estabelecimento do regime de colaboração do ensino público, concentrando os esforços no processo de municipalização do ensino; 3) reestruturação do ensino médio quanto ao currículo e a sua vocação para o mercado de trabalho; 4) municipalização do ensino fundamental mediante o estabelecimento de convênios com os municípios; 5) adoção de novos Parâmetros Curriculares, com a preocupação de elaborar propostas curriculares flexíveis, eficientes e de qualidade; 6) formação e valorização do Magistério por meio da capacitação, habilitação de professores leigos, gestão da qualidade na educação e reestruturação da carreira do Magistério, mediante a formalização de um "consórcio interuniversitário envolvendo a Unama, UFPA e UEPA em convênio com a SEDUC"; 7) financiamento da educação, o qual deve ficar a cargo dos municípios já que estes, segundo o Plano de Educação, "despontam como a rede de ensino que possui condições mais adequadas para aumentar o nível de investimento na qualidade do ensino no Pará" (SEDUC, 1999, p. 14-21).

Em relação ao princípio de garantir a educação de qualidade, destaco abaixo algumas das "diretrizes básicas para a melhoria da educação no Pará", assumidas como pontos centrais da política educacional defendida por Almir Gabriel:

"redução do déficit educacional; reduzir o nível de distorção série-idade existente no ensino fundamental e médio; gestão democrática da escola; capacitação e habilitação dos profissionais do magistério, sobretudo dos professores leigos; disseminar os programas de informática educativa na rede pública de ensino; extinção do turno intermediário na rede estadual; adoção dos Parâmetros Curriculares Nacionais de ensino fundamental e médio em toda a estrutura curricular de ensino; reorganizar e expandir o ensino médio e profissionalizante; concluir a municipalização do ensino fundamental" (SEDUC, 1999, p. 23-28). 
O Plano de Educação encerra ainda a formulação de seis programas institucionais por meio dos quais a excelência e a qualidade na oferta do ensino no Estado do Pará estarão asseguradas. São eles: 1) descentralização e municipalização das atividades educacionais, descentralizando totalmente as atividades administrativo-financeiras da Secretaria; 2) desenvolvimento do ensino fundamental, ampliando a oferta de vagas para crianças na faixa etária de 7 a 14 anos dos 96\% atuais para 98\%; 3) eficiência e qualidade na educação, elevando a taxa de aprovação no ensino fundamental, reduzindo a distorção série-idade, capacitando os professores da rede estadual; 4) desenvolvimento do ensino médio, ampliando a oferta de vagas para adolescentes de 1519 anos dos 79\% atuais para 90\%; 5) desenvolvimento da educação profissional, implantando novos cursos ou centros profissionalizantes com perspectiva de empregabilidade no mercado; 6) desenvolvimento da educação de jovens e adultos, intensificando as ações voltadas para a erradicação do analfabetismo no Pará (SEDUC, 1999, p. 29-35).

Como se pode constatar, são muitos e grandiosos os objetivos declarados pelo governo do Estado em favor da consolidação de uma educação de qualidade para todos. Todavia, a concretização dessas metas passa pela intensificação do processo de municipalização do ensino junto às prefeituras dos municípios paraenses, pois são elas as principais instâncias administrativas responsáveis pela oferta do ensino fundamental obrigatório à população em idade escolar.

Entretanto, o repasse compulsório dessa função para o âmbito municipal tende a produzir inúmeros problemas e dificuldades na operacionalização do sistema de ensino, uma vez que "a indução à municipalização vem se efetivando, contudo a prática tem mostrado que nem todos os municípios, que aderiram ao processo, têm condições de gerir redes/sistemas de ensino" (Oliveira, 1999).

\section{Considerações finais}

As reflexões desenvolvidas no decorrer deste estudo evidenciaram que o processo de reforma do Estado brasileiro desencadeado a partir dos anos 90 está impulsionando substanciais mudanças nas funções que as unidades federadas devem cumprir em relação à implementação das suas políticas sociais, especialmente aquelas definidas para o setor educacional.

Os governadores das unidades federadas ligados ao bloco de coalizão partidária que dá apoio às ações do governo federal constituem agentes essenciais na efetiva implantação das reformas políticas e educacionais formuladas pelo poder central da União. Essa junção 
serve como artifício político utilizado para unificar forças em defesa de determinado projeto sociopolítico, pois as coalizões correspondem a momentos em que são consolidadas grandes negociações entre candidatos e administradores públicos que, uma vez eleitos, supostamente honrarão as promessas feitas durante as campanhas publicitárias.

Nesse contexto, podemos supor que o endividamento dos estados para com a União converteu-se em moeda de troca entre essas esferas governamentais, ficando a rolagem da dívida condicionada à aceitação - por parte das unidades federadas consorciadas com o governo federal - dos programas de reformas político-econômicas e educacionais de abrangência nacional ${ }^{7}$. Portanto, a hegemonia exercida pelos "partidos governamentalmente relevantes" faz com que o ideário estatal torne-se uma posição dominante entre outras possibilidades existentes.

Além da afinidade político-partidária existente entre Almir Gabriel e Fernando Henrique Cardoso, o endividamento do Estado do Pará levou o governo local a sucumbir às determinações oriundas do governo central, particularmente no que concerne à implementação de um modelo de Estado baseado nos pressupostos da administração pública gerencial, assim como na adoção das reformas educacionais e curriculares destinadas à presumível melhoria da educação básica no Brasil.

Por outro lado, o processo de municipalização do ensino ao qual o Estado do Pará vem sendo sistematicamente submetido faz parte da política reformista monitorada pelo governo federal, a qual visa ajustar o poder estatal à lógica prevalecente na administração pública gerencial, tendo em vista o aumento da eficiência no que diz respeito à gestão dos recursos púbicos existentes para financiar o funcionamento do sistema educacional brasileiro como um todo.

Paralelamente ao discurso da municipalização, o Fundo de Manutenção e Desenvolvimento do Ensino Fundamental e Valorização do Magistério (FUNDEF) é apontado pelo governador paraense como um auxílio financeiro capaz de impulsionar as melhorias exigidas pela edu-

\footnotetext{
Seguindo essa mesma lógica de fazer do endividamento um instrumento de pressão para se conseguir o apoio político em favor de determinado plano ou programa governamental, o governador Almir Gabriel sancionou, no dia 05 de abril de 2000 , a Lei de n 107/2000, conhecida como Lei Colares, de autoria do Deputado César Colares (PSDB), a qual foi regulamentada com o propósito de "inibir irregularidades nas contas públicas municipais e ainda punir os prefeitos que não pagam em dia o funcionalismo público municipal". Além disso, a referida Lei proíbe os municípios inadimplentes de "celebrar convênios com o governo estadual e receber parcelas de recursos oriundos desses convênios". Do total de 143 municípios existentes no Pará, apenas 22 deles encontravam-se naquele momento em condições de estabelecer convênios com o governo paraense (LEI pune 120 prefeituras, 2000 , p. 1).
} 
cação nacional. Porém, na prática, o FUNDEF tem produzido sérios efeitos sobre o sistema de ensino das múltiplas e diversificadas realidades sociais em que ele se instala.

Tomando-se como exemplo a realidade paraense, especialmente no que se refere à composição da matrícula escolar, os impactos causados pelo FUNDEF são significativos, porém desfavoráveis quanto à universalização da freqüência escolar nas modalidades de ensino mais elementares.

Segundo o estudo realizado por Menezes, Gemaque e Guerreiro (2000), em que são abordadas as repercussões do FUNDEF na realidade de alguns municípios paraenses, torna-se notória e preocupante a sistemática retração do Estado do Pará na oferta e no financiamento da educação básica, particularmente nas suas modalidades pré-escolar, alfabetização e ensino fundamental. As considerações apresentadas pelas pesquisadoras são elucidativas, em especial quando destacam os seguintes aspectos:

- no período considerável de 1996 a 1999, as matrículas do préEscolar e das classes de alfabetização sofreram uma queda de $19,0 \%$ e $47,8 \%$ respectivamente, sendo a rede estadual a grande responsável por essa redução;

- o número de matrículas de crianças de 4 a 6 anos aumentou, o que revela que as crianças nessa idade passaram a freqüentar o ensino fundamental;

- no ensino fundamental, as matrículas foram aumentadas em torno de 17,9\%, mas, ao mesmo tempo em que o Estado reduziu a sua oferta em $28,8 \%$, os municípios, em apenas três anos, passaram por uma ampliação na oferta de vagas da ordem de 95,3\%;

- as responsabilidades administrativas das redes estadual e municipal para com o ensino fundamental inverteram-se no triênio 96/99, sendo que o processo de municipalização do ensino fundamental foi o grande responsável por tal impulso na participação dos municípios no oferecimento de tal modalidade educativa.

Portanto, muito menos que funcionar como antídoto à desigualdade tributária existente entre Estados e municípios, o FUNDEF "apenas atenua de modo temporário e fragmentário essa desigualdade". Além disso, é necessário ressaltar que "ainda que possa ter trazido melhorias para algumas redes estaduais e sobretudo municipais de ensino fundamental, ele não representa solução para a educação pública como um todo, nem para o conjunto dos profissionais da educa- 
ção, embora a remuneração de uma parcela possa ter melhorado com ele" (Davies, 1999, p. 32).

Assim, com a incorporação dos princípios da administração pública gerencial às novas funções que o Estado deve desempenhar, não há garantias de que o sistema educacional atinja melhores índices na sua eficácia e tampouco se tem assegurado a universalização na oferta de uma educação pública de qualidade. 
Referências bibliográficas

ALMIR começa demitindo 5 mil: Assessores e contratados os atingidos - Governo quer dispensar 50\% dos temporários. O Liberal. Belém, 4 jan. 1995.

ALMIR pode demitir até 15 mil. O Liberal. Belém, 17 jan. 1995. Conjuntura.

ALUNOS da "Rego Barros" se entusiasmam com a notícia. O Liberal. Belém, 5 maio 2000. Atualidades, p. 5.

ANDREWS, Christina W.; KOUZMIN, Alexander. O discurso da nova administração pública. In: BRESSER PEREIRA, Luiz Carlos; GRAU, Nuria Cunill (org.). O público não-estatal na reforma do Estado. Rio de Janeiro: Editora Fundação Getúlio Vargas, 1999, p. 97-129.

BRESSER PEREIRA, Luiz Carlos. A reforma do Estado nos anos 90: lógica e mecanismos de controle. Lua Nova: Revista de cultura e política, no 45,. p. 49-96, 1998.

Entre o Estado e o mercado: o público não-estatal. In: BRESSER PEREIRA, Luiz Carlos; GRAU, Nuria Cunill (org.). O público nãoestatal na reforma do Estado. Rio de Janeiro: Editora Fundação Getúlio Vargas, 1999, p. 15-48.

CORRÊA, Paulo Sérgio de Almeida. As políticas educacionais para o Ensino Médio no Pará: uma análise histórica (1964-1982). 1997. Dissertação (Mestrado em) - PUC, São Paulo. 1997.

. O ensino médio no Estado do Pará segundo as estatísticas oficiais: os impasses das políticas públicas educacionais e os desafios para o século XXI. Belém:UFPA/NAEA, 1999 (Papers do NAEA).

DAIN, Sulamis; SOARES, Laura Tavares. Reformas do Estado e políticas públicas: relações intergovernamentais e descentralização desde 1988. In: OLIVEIRA, Marco Antônio de (org.). Reformas do Estado e políticas de emprego no Brasil. Campinas:UNICAMPI/IE, 1998, p. 31-72.

DAVIES, Nicholas. O FUNDEF e o orçamento da educação: desvendando a caixa preta. Campinas:Autores associados, 1999. 
DINIZ, Eli. Em busca de um novo paradigma: a reforma do Estado no Brasil dos anos 90. Perspectiva: Revista da Fundação SEAD, São Paulo, v. 10, nº 4, p. 13-26, out.-dez. 1996.

DÍVIDA do Estado é gigantesca, diz Almir. Diário do Pará. Belém, 3 jan. 1995.

ESTADO começa a demitir servidores. Diário do Pará. Belém, 4 jan. 1995.

FHC exorta o povo a mudar o País. O Liberal. Belém, 2 jan. 1995. Seção Política, p. 5.

GABRIEL, Almir. Mensagem do Governo do Pará à Assembléia Legislativa. Belém-Pará, 1999, p.12.

GOVERNO descobre "marajás": Gueiros revela a existência de funcionários do Estado que recebem até R\$ 17 mil. O Liberal. Belém, 12 jan. 1995. Conjuntura.

IBGE, Centro de documentação e disseminação de informações. Brasil em números. Rio de Janeiro: IBGE, col. 1, p. 151-158, 1999.

LEI pune 120 prefeituras: apenas 23 municípios estão em condições de assinar convênios com o Estado. O Liberal. Belém, 9 abr. 2000. Painel, p. 1.

LOUREIRO, João de Jesus Paes. Descentralização, municipalização e FUNDEF no Pará. In: COSTA, Vera Lúcia Cabral (org.). Descentralização da educação: novas formas de coordenação e financiamento. São Paulo: FUNDAP: Cortez, 1999, p. 122-140.

MENEGUELLO, Rachel. Partidos e governo no Brasil contemporâneo (1985-1997). São Paulo: Paz e Terra, 1998.

MENEZES, Janaína; GEMAQUE, Rosana; GUERREIRO, Telma. Impactos do FUNDEF na composição das matrículas no estado do Pará. Caxambu: ANPEd, 2000.

NO rumo da responsabilidade social: lançamento do projeto demonstra interesse dos empresários em novo modelo de gerenciamento. $O$ Liberal. Belém, $1^{\circ}$ abr. 2000. Atualidades, p. 5.

OLIVEIRA, Cleiton de. A municipalização do ensino brasileiro. In: ARELARO, Lisete R. G. et al. (org.). Municipalização do ensino no Brasil: algumas leituras. Belo Horizonte: Autêntica, 1999, p. 11-36. 
PROJETO ajuda crianças ligadas ao Riacho Doce. O Liberal. Belém, 5 maio 2000. Atualidades, p. 5.

SECRETARIA DE ESTADO DE EDUCAÇÃO DO PARÁ (SEDUC). Plano Estadual de Educação - 1995/1999. Belém: SEDUC, 1995.

. Municipalização do ensino fundamental no Pará. Belém: SEDUC, 1996, p. 26-28.

. Plano Estadual de Educação - 1999-2003. Belém: SEDUC, 1999.

SOARES, Maria Clara Couto. Banco Mundial: políticas e reformas. In: DE TOMASI, Lívia; WARDE, Mirian Jorge; HADDAD, Sérgio (org.). O Banco Mundial e as políticas educacionais. São Paulo: Cortez, 1999, p. 15-40.

SOLUÇÃO para 13º só sexta-feira. Diário do Pará. Belém, 3 jan. 1995. 


\section{Estado e Políticas Públicas na Amazônia: gestão de recursos naturais}

\section{Maria Célia Nunes Coelho(org.) (2000)}

Reúne autores/pesquisadores em busca de uma compreensão dos processo de mudanças políticos e sociais, para explicar as relações entre Estado e sociedade, entre políticas públicas e os resultados sociais e físicos ambientais do desenvolvimento e das ações de proteção ambiental e regulação do uso de recursos naturais na Amazônia nos últimos 30 anos. O livro é dividido em 3 partes, sendo os capítulos assinados por Lígia Simonian, Maria Célia Coelho e Norbert Fenzl

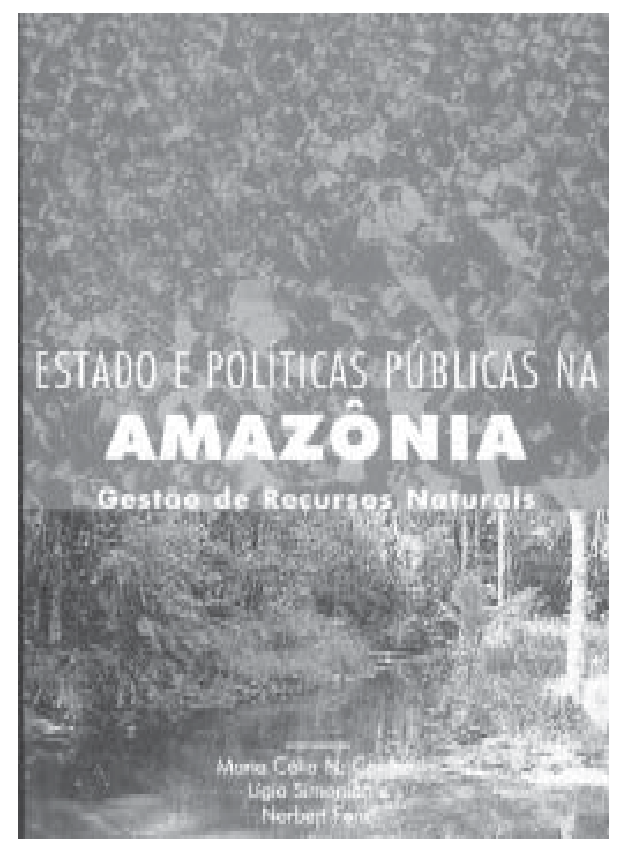

\section{Campesinato e Estado na Amazônia}

Impactos do FNO no Pará angel Tura

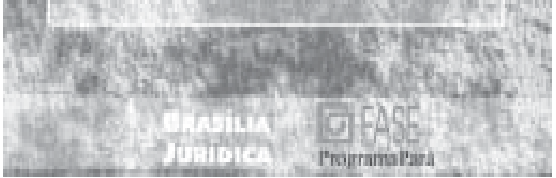

Campesinato e Estado na Amazônia: impactos do FNO no Pará (2000)

\section{Letícia Rangel Tura}

Francisco de Assis Costa(orgs)

Os dados e as conclusões da pesquisa do FNO-FASE/FETAGRI/NAEA/IMAZON apresentados neste livro merecem ser amplamente divulgados como base para a priorização da produção familiar rural nas políticas publicas. Aponta diversos problemas na aplicação deste crédito pioneiro, que precisam ser corrigidos tanto pelo banco como pela assistência técnica e pela categoria. 